Epidemiology of the townsman's blight

\author{
D.G.T. Williams
}

Rural Conservation in Inter-War Britain. By John Sheail. Pp.272. ISBN 0-19-8232-36-5. (Oxford University Press: 1981.) $£ 16.50, \$ 49.50$. The Countryside: Planning and Change. By Mark Blacksell and Andrew W. Gilg. Pp.262. Hbk ISBN 0-04-711008-2; pbk ISBN 0-04-711009-0. (George Allen \& Unwin: 1981.) Hbk £13, \$35; pbk £6.95, \$17.95.

A "widespread general concern" about the scale and nature of change in the countryside is (in the words of Blacksell and Gilg) "a relatively recent post-war development"; but, as Sheail argues, "the inter-war period was so critical and innovative that precedents can be found for almost every aspect of rural planning and conservation today". Together these two books offer a useful blend of historical perspective and identification of current problems, and they remind us that there is a rich vein of source material being tapped and yet to be tapped in studies of planning and the countryside in Britain. All of the authors are geographers: their approach, however, is widely based and of value to those concerned with economics, law, administration and other aspects of a complex subject. John Sheail, who is a historical geographer, has written his book as one of the Oxford Research Studies in Geography; Mark Blacksell and Andrew Gilg, both from Exeter University, have produced their volume as one of the Resource Management Series edited by Richard Munton and Judith Rees.

As a lawyer, I found that John Sheail's book offers a revealing analysis of the complicated and hesitant movement which culminated, after the Second World War, in comprehensive planning legislation dating from 1947. Against a background of the "economic and social malaise of the inter-war years" he examines a variety of experiments in local, regional and national planning secured through the initiative of legislators, officials and private pressure groups. In the country as a whole eloquent voices raised the spectre, in the words of Geoffrey Boumphrey (in one of the contributions to Britain and the Beast in 1938, a book which is mentioned by Sheail in his concluding chapter), of

the march of an inglorious suburbia across our countryside; the wanton sterilization of much of our most productive agricultural and marketgarden land; the marring of vista upon vista, where country still remains, by the erection of unsuitable buildings, by thoughtless felling of trees, by Philistine methods of road-making and road-widening - in short the blighting touch of the townsman upon the country.

The countryside was seen as threatened as never before by the "suburbanizing trend" reflected in the spread of the towns and of townspeople, in greater mobility achieved through modern traffic and new roads, in the search for new opportunities to enjoy the countryside for recreation or to adapt the countryside (allowing, for instance, for afforestation or new industrial growth) in the public interest.

One looks in vain for a consistent or positive approach in the inter-war years to the problem of reconciling the need for change and the desire to preserve. Rural conservationists succeeded in numerous battles but seemed a long way in 1939 from winning the war against what they saw as the evil of uncontrolled infringement of the old countryside. Sheail takes a balanced and understanding view of what they sought to achieve and how far they succeeded; and it is helpful to be told in the course of his book of the circumstances in which the Town and Country Planning Act 1932 was passed; of private legislation such as the Malvern Hills Act 1924 (later to be judicially considered, incidentally, by the House of Lords in Pyx Granite Co. Ltd. v Ministry of Housing and Local Government |1960| Appeal Cases 260); of the emergence of planning consultants and of the role of geographers in land-use surveys; of the work of such bodies as the Council for the Preservation of Rural England (founded in 1926), the Forestry Commission (established by statute in 1919) and the Youth Hostels Association (founded in 1930); of planning delays in the Ministry of Health and of "a somewhat ambivalent attitude" adopted towards statutory planning by the Ministry of Agriculture; and of numerous individuals (including Evelyn Sharp) who contributed in all sorts of ways to the national and local debates and controversies of the inter-war period. Drawing upon a wide range of original material, the author - admittedly on a selective basis, for the subject is vast manages to develop a carefully structured account of the problems of planning and conservation.

The same problems are with us today, though the emphasis may have altered and the statutory framework has changed out of all recognition. In their work, Blacksell and Gilg set out to assess "the impact of the policies and plans that have proliferated during the past thirty years to guide the process of change in the rural landscape of Great Britain". They detect many inadequacies in the present system, notably the absence of co-ordinated guidance in the process of change. We are told about the work of the Ministry of Agriculture, Fisheries and Food, the Forestry Commission, the Department of the Environment, the Countryside Commission and the Nature Conservancy Council; and a number of complex issues are explored, often on a basis of original material (particularly drawn from the authors' own case studies in Devon), on such topics as the nature and measurement of land use change, planning and land use, settlement planning, settlement change, and management in the countryside. For many readers a good deal of the authors' material will be unfamiliar, but there is clearly sufficient evidence of the value of the attempt by the Resource Management Series editors to provide "an interdisciplinary vehicle for major contributions from scholars and practitioners with a wide variety of academic backgrounds".

Problems of planning and conservation obviously loom large in a small and overcrowded country such as Britain - where the population, as Blacksell and Gilg point out, rose from 38.2 million in 1901 to an estimated 56 million in 1976. A study of the countryside alone becomes even more complex when one considers issues of pollution and the new and urgent demands for energy. Within their own terms of reference, these two books are important contributions to a subject of immense difficulty, riddled with conflicting interests, and they do much to correct what has perhaps been an overemphasis on town as opposed to country planning in the system which has evolved painfully over so many years.

D.G.T. Williams is President of Wolfson College, Cambridge, and was formerly a member of the Commission on Energy and the Environment (1978-1981) and the Clean Air Council (1971-1979).

\section{Enshrouded by prose}

\section{David Davies}

Cosmos and Creator. By Stanley L. Jaki. Pp. 168. Pbk ISBN 0-7073-0285-4. (Scottish Academic Press: 1981.) £3.25.

Professor Jaki, a Benedictine priest with a long-time interest in the theological implications of science, has written Cosmos and Creator to make available the major points in his other books on creation "in a concise form for the wider public". In this I believe he flatters the wider public (in which $I$ include myself) with a breadth of learning that it does not possess. A sentence such as

the presence of nominalism is merely nominal in the thought of Buridan and Oresme, while the presence there of a pre-Ockhamist traditional notion of creation is rather robust

is a typical example of some of the heavy weather encountered; I, for one, was grateful to my Fontana Dictionary of Modern Thought for providing the glossary that Jaki should have included. And even when all the words are easily understood, the author writes too often in an obscure way for my taste.

No less revealing should it seem that in Eddington's and Jeans' success of making a fad (very superficially, to be sure) [of] the inference 